This article was downloaded by: [Brought to you by Brunel University] On: 27 July 2011, At: 01:09

Publisher: Routledge

Informa Ltd Registered in England and Wales Registered Number: 1072954 Registered

office: Mortimer House, 37-41 Mortimer Street, London W1T 3J H, UK

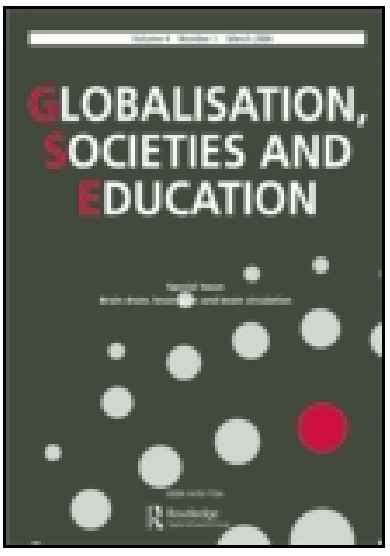

\title{
Globalisation, Societies and Education
}

Publication details, including instructions for authors and subscription information:

http:// www.tandfonline.com/ loi/ cgse20

\section{International/transnational spaces of education}

J ohanna Waters ${ }^{a} \&$ Rachel Brooks ${ }^{b}$

a University of Birmingham, UK

${ }^{b}$ Brunel University, UK

Available online: 24 J un 2011

To cite this article: J ohanna Waters \& Rachel Brooks (2011): International/transnational spaces of education, Globalisation, Societies and Education, 9:2, 155-160

To link to this article: http:// dx. doi.org/ 10.1080/ 14767724.2011.576933

\section{PLEASE SCROLL DOWN FOR ARTICLE}

Full terms and conditions of use: http://www.tandfonline.com/page/terms-andconditions

This article may be used for research, teaching and private study purposes. Any substantial or systematic reproduction, re-distribution, re-selling, loan, sub-licensing, systematic supply or distribution in any form to anyone is expressly forbidden.

The publisher does not give any warranty express or implied or make any representation that the contents will be complete or accurate or up to date. The accuracy of any instructions, formulae and drug doses should be independently verified with primary sources. The publisher shall not be liable for any loss, actions, claims, proceedings, demand or costs or damages whatsoever or howsoever caused arising directly or indirectly in connection with or arising out of the use of this material. 


\section{INTRODUCTION}

\section{International/transnational spaces of education}

This special issue of Globalisation, Societies and Education emerges out of an ESRCfunded seminar series on 'Changing Spaces of Education: New Perspectives on the Nature of Learning' (2009-2010). These seminars sought to examine explicitly the spaces in which contemporary education and learning take place, and the ways in which these have been gradually transformed through technological, economic, social and political change (such as the widespread use of Information and Communication Technologies [ICTs] and the consolidation of knowledge-based economies around the world). The seminars highlighted the need to appreciate the plurality of spaces (such as homes, workplaces, policy spaces, international/transnational space and cyberspace) associated with current notions of education. They also represented an explicit attempt to bring together, under the same roof, educationalists, geographers, sociologists, policy makers and educational practitioners; hitherto, these groups have rarely engaged with each other in tackling questions of space in relation to education and learning. Consequently, a crucial interdisciplinary understanding of these emergent spaces of education has materialised, represented in part within the pages of this special issue.

As will become clear, the collection of papers presented here tackles one particular aspect of the transformation of education, focussing on international/transnational space. Over the last 10 years, international/transnational education ${ }^{1}$ has shifted from a topic of peripheral and peculiar interest amongst academics, practitioners and policy makers to occupy the centre stage of many contemporary debates. In a recent letter to The Observer newspaper (5 March 2011), 16 vice-chancellors of UK universities expressed their 'profound concern' over government plans to limit severely the number of visas issued to students coming to the United Kingdom from outside the European Union. It has been shown that as many as one in five degrees conferred by UK universities today is awarded to an international student (International Focus 2009). As suggested in the letter to The Observer, international students are increasingly being seen as a panacea for universities, faced with substantial cuts in government funding - and this view pertains not just to the United Kingdom but elsewhere (as Nick Lewis describes in his paper in relation to New Zealand, and as has been documented in previous issues of this journal).

Despite their numerical importance - there are currently more than three million individuals studying for a tertiary-level qualification outside their home country (OECD 2009) - international students represent only one facet of the internationalisation/transnationalisation of contemporary education. In this special issue, we were therefore keen to represent the breadth of our understanding of international/ transnational education - it includes not just higher education but also primary, secondary, and sub-/post-degree qualifications; it encompasses not only students, but 
parents, academics, politicians and managers. Whilst the majority of work on internationally mobile students has focused on 'east' to 'west' flows, we were keen to represent other, less 'conventional' student groups (the paper by Russell King and colleagues in this special issue, for example, looks at English international students). International/transnational education is also not always about mobility - Mary Hayden writes about the role that international schools play in educating 'locals' within many countries. Similar processes have been seen also in relation to higher education British, American, Canadian, Australian and Chinese universities are operating outside their home countries, offering 'international' credentials to students 'at home'. Such trends towards the 'offshoring' of higher education are perceived by some commentators as the future of international education (Bone 2010; Garrett and Verbik 2004). This special issue of Globalisation, Societies and Education reflects our attempt to illustrate, in part, the diversity that falls under the banner of international/ transnational education.

Here, we have selected five papers, which represent different but complementary perspectives on international/transnational spaces of education. These papers are both empirically strong and theoretically ambitious, and indicate an important, unified attempt by geographers and educationalists to engage seriously with the implications of emergent international/transnational spaces for education and learning. The first paper by Russell King, Allan Findlay, Jill Ahrens and Mairead Dunne focuses on the ways in which opportunities for international study can work to 'reproduce advantage' in UK society. The paper draws on the results of an extensive questionnaire survey (of 1400 Year 13 and 'sixth-form' students in England), to examine students' plans and intentions with regards to studying overseas. Their data point to the privileged nature of international education in a number of ways. First, it is clearly a minority pursuit, with only $3 \%$ of students surveyed actually applying to go abroad. Secondly, the motivations of students would seem also to reflect the views of a very select group of advantaged young people - those concerned with accessing elite overseas institutions on the one hand, and those keen to pursue a 'good time' on the other. Both 'types' of student possess a rather privileged perspective on the world (Bourdieu 1984); these are individuals for whom, King et al. write, 'mobility is already part of their habitus' (259). Perhaps the most important finding emerging from this paper, however, concerns the way in which access to international education solidifies an alreadyexisting elite, potentially enhancing these young people's employability within British and international labour markets. This, King et al. argue, has policy implications in relation to issues of 'widening participation' and 'brain drain' and more directly to the second phase of the Prime Minister's Initiative for International Education (PMI2), launched by Tony Blair in 2006 with the aim of increasing outward flows of students from the United Kingdom to overseas higher education institutions (HEIs). King et al.'s paper reflects a growing and important trend in the literature on international/ transnational education to focus on issues of class inequality and elite reproduction (see Hall and Appleyard in this issue; Brooks and Waters 2009; Waters 2006, 2007; Waters and Brooks 2010).

The next paper, by Heike Jöns, focuses on social relations and inequalities of a different kind - specifically those of gender. Jöns's recent work has been largely concerned with understanding the transnational mobility of academic researchers, and in this paper she turns the spotlight on to the differential experiences of male and female academics. Drawing on a substantive dataset, which includes survey data, secondary longitudinal statistics (from the early 1980s to the late 2000s) and semi-structured 
interviews with Humboldt research fellows (who travelled to Germany on research visits), she argues that female researchers have experienced significantly less transnational mobility within their careers than their male counterparts. This is an important finding, as research has shown that academic mobility can have considerable positive effects on travelling academics themselves, their students, research groups and institutions (Ackers 2000, 2010). This paper also, significantly, broadens the scope of the discussion of inequalities in international/transnational education beyond students and social-class.

Educationalist Mary Hayden provides the third contribution to this collection of papers, and this is the only paper of the five to address school-level international education. Hayden's article examines the growth in the 'international school' sector, from its inception in the 1920s, when international schools catered largely for the children of expatriate diplomats and the employees of transnational corporations. As the sector grew (as a consequence, she argues, of globalisation), so too did the diversity apparent within it, and the 'international school sector' came to encompass schools of many different types. Today, the majority of international schools cater not primarily for the children of expatriates, but for local aspiring elites. One of the overarching messages of Hayden's paper concerns the enduring class privilege underpinning the growth of this sector. International schools, like international education more broadly, are clearly not accessible to all. The commercial nature of these newer schools is also highly apparent in this paper - international schools represent a (lesser known) part of the growth in an international education industry.

The international education industry is the subject of the fourth paper in our collection, by Nicolas Lewis. The geographical focus of this paper is New Zealand; it traces the highly political and extremely strategic way in which the branding and selling of international education in New Zealand has been undertaken. Internationalisation of higher education has certainly not occurred 'by accident', but has involved significant state intervention and the active 'production and framing of economic knowledge' (222). Lewis makes a useful contribution to a very important debate around the seemingly rife and overpowering commercial intentions underpinning many internationalisation endeavours, whether undertaken by states, universities, colleges or schools. The consolidation of a multi-billion dollar international education industry (globally) clearly necessitates a more sustained academic critique than has been attempted to date.

The final paper, by Sarah Hall and Lindsey Appleyard, continues this theme of international education as an 'industry', but widens the debate to examine the relationship between international credentials and broader labour market processes, and moves beyond higher education to examine subsequent work-place learning. In particular, they are interested in exploring how international and local academic credentials, gained within the workplace setting, intersect with the transnationalisation of elite financial labour markets. They draw upon substantive research conducted into workplace education (undertaken within 10 years of individuals starting their career), amongst investment bankers in London. This included in-depth interviews with the bankers themselves, business school lecturers and managers (in the United States and United Kingdom), human resource managers within London-based investment banks, and practitioners within for-profit specialist financial business education companies and professional associations in the United Kingdom. Hall and Appleyard take seriously the role that the workplace now has in providing (as opposed to being the mere recipient of) valuable education and skills. Notions of 'international' and 
'localised' spaces are invoked, as Hall and Appleyard argue that their findings: 'point to the important spatialities of workplace learning and education as individuals in finance seek to enhance their career progression by using different forms of education to both facilitate potential future international career mobility whilst also temporarily embedding themselves into the specific demands of local elite labour markets' (175). There are clear links, here, with Heike Jöns's paper, where the role of international mobility in affecting career progression is considered. Hall and Appleyard conclude with a call to bring work within the discipline of geography and the sociology of education into closer dialogue - an aim with which we would strongly concur.

Taken as a whole, the papers highlight some common themes, which in turn reflect wider ongoing debates about the internationalisation and transnationalisation of education. The starkest of these is that of social inequalities. International/transnational forms of education would seem, on the whole, to reproduce and bolster preexisting relations of social privilege, in much the way that Bourdieu $(1984,1996)$ has documented for elite schools and colleges in France. Indeed, Bourdieu's (1986) conceptualisations of 'capital' are as applicable to understanding international/ transnational forms of education as they are for theorising national education systems and the localised reproduction of privilege. Individuals who embark on international mobility for education (whether students or academics), or engage in the acquisition of international skills and qualifications, are invariably drawn from those sections of the population in possession of the most prolific capital (economic, social and cultural). Thus, King et al. show in their paper that those students with the 'best' academic results apply for overseas study, as do those with prior connections (such as holidays and family members) abroad. As Bourdieu has also observed, capital has a tendency to reproduce itself, and (international) education facilitates this process. The factors described by King et al. (conceptualised as the prior possession of cultural and social capital) influence strongly the decision to acquire an international education (not to mention the significance of the weighty financial costs attached to overseas study in impacting decision making), which in turn facilitates labour market success (and thus the further accumulation of economic, social and cultural capital). This perspective is mirrored, also, in the papers by Hayden and Hall and Appleyard. Jöns's paper adds another dimension to the discussion of international/transnational education and social inequalities. Her focus on gender is a valuable one: although the importance of gender has been raised before in work on academic mobility (see Ackers 2000, 2010), as we have argued elsewhere (Brooks and Waters 2011), taken as a whole, surprisingly few studies of international education examine gender as an important differentiating factor in individuals' experiences.

A second overarching theme to have emerged in relation to this discussion of international/transnational education is the commercialisation and marketisation of learning in response to neo-liberal pressures and imperatives. As Lewis infers in his paper, international education has become 'big business', with weighty economic advantages and risks attached. The development of 'national' education brands, as several authors have noted, is very much a large scale (and expensive) commercial endeavour (Lewis 2005; Sidhu 2006; Waters 2008). Increasingly, many universities and colleges are making use of private education agencies to attract and recruit international students onto their programmes. Some enlist the services of large commercial education companies (such as Kaplan and Laureate) to help deliver programmes or to enable students to attain the necessary qualifications for subsequent 
university entrance. As Hayden notes in her paper, 'groupings of international schools have [recently] been established on a more commercial footing' (212) - and she proceeds to list the major companies that have been involved in the setting up and running of international schools, which have proliferated in places such as Hong Kong and Shanghai. Language testing - a requirement of most university courses - is often carried out on a commercial basis by private firms. The building of large offshore campuses of 'domestic' universities is partly financed and enacted by business interests. And beyond university too, learning has become, to a certain extent, commercialised. This was illustrated in Hall and Appleyard's paper, which observes the rise in 'other forms of financial business education' (176) - Masters programmes run by business schools continue to provide one sort of post-degree qualification to financial elites, but these are being rivalled by the offerings of for-profit, specialist business education companies. These examples, indicating the role of the private sector in the expansion of international/transnational education, just scratch the surface of the extent to which economic imperatives drive the expansion of this industry. Overall, this is a complex and multi-faceted process; something we hope is largely captured by the excellent contributions to follow.

Johanna Waters

University of Birmingham, UK

Rachel Brooks

Brunel University, UK

\section{Acknowledgements}

We would like to thank Alison Fuller and John Holford for their participation in the organisation of the 'Changing Spaces' seminar series, and for their general support and collegiality. We are very grateful to all those individuals who participated in the seminar series, as presenters and audience members. Our thanks also go to Susan Robertson for encouraging this project.

\section{Note}

1. International/transnational education can be loosely defined as formal education that takes place outside of local or national education systems, whether that is delivered 'at home' or overseas.

\section{References}

Ackers, L. 2000. The participation of women researchers in the TMR Marie Curie Fellowships. $\mathrm{ftp} / / / \mathrm{ftp}$.cordis.europa.eu/pub/improving/docs/women_final_rpt_3march2000.pdf (accessed March 17, 2011).

Ackers, L. 2010. Internationalisation and equality: The contribution of short stay mobility to progression in science careers. Recherches sociologiques et anthropologiques 41, no. 1: 83-103.

Bone, D. 2010. Internationalisation of HE: A ten year view. http://webarchive.nationalarchives. gov.uk/tna/ +/http://www.bis.gov.uk/wp-content/uploads/2009/10/HE-InternationalisationBone.pdf (accessed September 13, 2010).

Bourdieu, P. 1984. Distinction: A social critique of the judgement of taste. Cambridge, MA: Harvard University Press.

Bourdieu, P. 1986. The forms of capital. In Handbook of theory and research for the sociology of education, ed. J.G. Richardson, 241-58. New York: Greenwood Press. 
Bourdieu, P. 1996. The state nobility: Elite schools in the field of power. Stanford, CA: Stanford University Press.

Brooks, R., and J. Waters. 2009. 'A second chance at success': UK students and global circuits of higher education. Sociology 43, no. 6: 1085-102.

Brooks, R., and J. Waters. 2011. Student mobilities, migration and the internationalization of higher education. Basingstoke: Palgrave Macmillan.

Garrett, R., and L. Verbik. 2004. Transnational delivery by UK higher education, part 1: Data and missing data. London: The Observatory on Borderless Higher Education Report, 10.

International Focus. 2009. UK HE International Unit. http://www.international.ac.uk/resources/ International\%20Focus\%20issue\%2032.04.02.09.pdf (accessed February 7, 2009).

Lewis, N. 2005. Code of practice for the pastoral care of international students: Making a globalising industry in New Zealand. Globalisation, Societies and Education 3, no. 1: 5-47.

OECD. 2009. Education at a glance. Paris: OECD Publications.

Sidhu, R. 2006. Universities and globalization. To market, to market. Mahwah, NJ: Laurence Erlbaum Associates.

The Observer. 2011. Comment. March 5. http://www.guardian.co.uk/theobserver/2011/mar/05/ letters-international-student-cuts (accessed March 21, 2011).

Waters, J.L. 2006. Geographies of cultural capital: Education, international migration and family strategies between Hong Kong and Canada. Transactions of the Institute of British Geographers 31, no. 2: 179-92.

Waters, J.L. 2007. 'Roundabout routes and sanctuary schools': The role of situated educational practices and habitus in the creation of transnational professionals. Global Networks 7, no. 4: 477-97.

Waters, J.L. 2008. Education, migration and cultural capital in the Chinese Diaspora: Transnational students between Hong Kong and Canada. New York: Cambria Press.

Waters, J., and R. Brooks. 2010. Accidental achievers? International higher education, class reproduction and privilege in the experiences of UK students overseas. British Journal of Sociology of Education 31, no. 2: 217-8. 